Научная статья

УДК 581.9

DOI 10.18101/2587-7143-2021-4-16-28

\title{
ТАКСОНОМИЧЕСКАЯ СТРУКТУРА ФЛОРЫ НИЖНЕГО ПРИАМУРЬЯ
}

\author{
(C) Крюкова Мария Викторовна \\ доктор биологических наук, \\ Институт водных и экологических проблем ДВО РАН \\ Россия, 680000, г. Хабаровск, ул. Дикопольцева, 56 \\ flora@ivep.as.khb.ru
}

\begin{abstract}
Аннотация. Дан анализ таксономической структуры флоры сосудистых растений Нижнего Приамурья, включающей 2240 видов из 760 родов и 158 семейств, что составляет $80 \%$ видового состава российской части бассейна р. Амур. Аборигенная флора объединяет 1801 вид из 602 родов и 152 семейств. Адвентивный комплекс представлен 439 видами из 256 родов и 57 семейств, что составляет 19,6\% природной флоры. Видовое разнообразие, количественные характеристики аборигенной и адвентивной флоры сосудистых растений Нижнего Приамурья сопоставимы с флорами южного предела распространения таежных экосистем Голарктики. Определено место флоры водоемов Нижнего Амура в системе флоры бассейна р. Амур. Спектр ведущих по числу видов семейств и родов соответствует географическому положению территории (ведущее положение в семейственном спектре Asteraceae, Cyperaceae, Poaceae, Ranunculaceae, Rosaceae, Polygonaceae, в родовом спектре - Carex, Artemisia, Salix, Viola, Saxifraga, Poa, Saussurea). Специфика флоры определяется сочетанием элементов бореальной и суббореальной флор Восточной Азии.

Ключевые слова: флора, вид, род, семейство, таксономический спектр, видовое разнообразие, Нижнее Приамурье.
\end{abstract}

\section{Для цитирования}

Крюкова М. В. Таксономическая структура флоры Нижнего Приамурья // Вестник Бурятского государственного университета. Биология, география. 2021. № 4. С. 16-28.

Введение. Нижнее Приамурье занимает южную часть Хабаровского края и охватывает обширную долину реки от приустьевой части р. Уссури до Амурского лимана. Расположение этой территории на восточной окраине Азии в зоне активного взаимодействия материка и Тихого океана определяет высокую контрастность природно-климатических условий, сочетание целого ряда природных рубежей высокого ранга (геологические, геоморфологические, зональноклиматические, гидротермические и т. д.) и усилению процессов межгеокомпонентных взаимодействий. Богатство и пестрота флоры Нижнего Приамурья обусловлены высокой степенью разнообразия растительного покрова, общей ландшафтной пестротностью, географической провинциальностью и развитием азональных процессов в формировании ландшафтов, которые в совокупности определяют разнообразие экологических условий во времени и пространстве и в конечном итоге - зоны контактов различных по генезису фратрий растительных формаций.

Понимание природных и антропогенных механизмов изменения видового разнообразия и структуры растительного покрова в пространстве и во времени 
являются основой биологических, биогеографических, экологических, эволюционных, созологических исследований. С этой точки зрения зоны контактов различных растительных формаций выступают в качестве важного источника информации о процессах формирования, поддержания биологического разнообразия и могут рассматриваться в качестве модели для изучения, мониторинга и прогнозирования реакции биологического разнообразия растительного покрова на естественные и антропогенные изменения природной среды. Интерес к флоре Нижнего Приамурья определяется ее расположением в структуре зональноклиматического экотона «тайга — хвойно-широколиственные леса», что позволяет рассматривать ее как уникальный объект изучения факторов и механизмов формирования региональной структуры растительного покрова экотонных территорий.

Нижнее Приамурье издавна привлекает внимание исследователей, обширна и литература по флоре и растительности этого региона. Вместе с тем, несмотря на почти 200-летний период изучения растительного покрова бассейна р. Амур, отсутствуют сводные полные работы, посвященные составу и анализу флоры этой территории. Существующие флористические работы по Дальневосточному региону, Хабаровскому краю или отдельным локальным территориям в отношении рассматриваемой территории либо устарели, либо не полностью отражают современное состояние растительного покрова Нижнего Приамурья. В связи с его неравномерностью изученности задачи обобщения и анализа всей информации по флоре этой территории весьма актуальны.

Цель исследований - инвентаризация природной флоры, анализ ее таксономической структуры для выявления закономерностей и тенденций ее развития в условиях зонально-климатического экотона.

Объекты, методы исследования. Объектом исследований является аборигенная флора Нижнего Приамурья, при этом предметом исследования выступают закономерности структурной организации видового разнообразия растительного покрова в условиях зонально-климатического экотона «тайга - хвойношироколиственные леса» или неморально-бореального экотона.

Изучение состава и структуры видового разнообразия растительного покрова экотонных систем предполагает комплексное использование методов сравнительной флористики, ботанической географии.

В основу настоящей работы легли собственные наблюдения и сборы, полученные в течение 1993-2020 гг. В процессе работы проведены детальные маршрутные полевые исследования по общепринятым методикам ботанических исследований ${ }^{2}$ Время полевых работ (май - октябрь) совпадало с периодом вегетации растений. В результате было собрано более 11000 гербарных образцов, которые в совокупности с геоботаническими описаниями автора (около 900) и предшествующих исследователей послужили основой для составления списка видов, дальнейшего анализа и создания базы данных по флоре Нижнего Приаму-

\footnotetext{
${ }^{1}$ Методические предложения по созданию системы постоянных пробных площадей на особо охраняемых лесных территориях. Москва: Наука, 1988. 27 с.; Мониторинг биологического разнообразия лесов России: методология и методы / ответственный редактор А. С. Исаев. Москва: Наука, 2008. 453 с.; Полевая геоботаника. Москва; Ленинград: Наука, 1959-1976. T. I-V.
} 
рья. Материалы хранятся в ИВЭП ДВО РАН (КНА), частично переданы в гербарии БПИ ДВО РАН (VLA), БИН РАН (LE).

Дополнительно были использованы фондовые коллекции, хранящиеся в научных учреждениях России (Ботанический институт им. В. Л. Комарова РАН (БИН PAH, LE), Главный ботанический сад им. Н. Н. Цицина РАН (ГБС РАН, МНА), Московский государственный университет им. М. В. Ломоносова (МГУ, MW), Биолого-почвенный институт ДВО РАН (БПИ ДВО PAH, VLA), Институт водных и экологических проблем ДВО РАН (ИВЭП ДВО РАН, КНА), а также коллекции ряда ботаников, работавших на этой территории.

Анализ флоры основан на оригинальной базе данных видового разнообразия Нижнего Приамурья, включающей информацию по распространению, жизненным формам, экологии и биологии видов. При анализе флоры использовались традиционные методики и математические методы [17, 18, 22, 23].

\section{Результаты и их обсуждение}

Флора Нижнего Приамурья включает 2240 видов из 760 родов и 158 семейств, что составляет $80 \%$ видового состава российской части бассейна р. Амур [5]. Аборигенная флора объединяет 1801 вид из 602 родов и 152 семейств. Адвентивный комплекс представлен 439 видами из 256 родов и 57 семейств, что составляет 19,6\% природной флоры. Занимая нарушенные места обитания близ населенных пунктов, по обочинам дорог, на сельскохозяйственных полях, техногенных территориях, а также свободные места по берегам рек, на обнаженных глинистых и каменистых осыпях, эти растения достаточно широко распространились в долине Амура. Многие из них занимают достаточно устойчивые позиции.

Видовое разнообразие, количественные характеристики аборигенной и адвентивной флоры сосудистых растений Нижнего Приамурья сопоставимы с флорами южного предела распространения таежных экосистем Голарктики (табл. 1).

Таблица 1

Количественные характеристики южного предела распространения бореальных флор Голарктики*

\begin{tabular}{|l|c|c|c|c|c|c|}
\hline Регион & $\begin{array}{c}\text { Число } \\
\text { видов }\end{array}$ & $\begin{array}{c}\text { Число } \\
\text { родов }\end{array}$ & $\begin{array}{c}\text { Число } \\
\text { семейств }\end{array}$ & $\begin{array}{c}\text { Среднее } \\
\text { число видов } \\
\text { в роде }\end{array}$ & $\begin{array}{c}\text { Показатель } \\
\text { автоном- } \\
\text { ности флоры }\end{array}$ & $\begin{array}{c}\text { Степень } \\
\text { адвен- } \\
\text { тизации }\end{array}$ \\
\hline Нижнее Приамурье & 2240 & 760 & 158 & 2,9 & $-0,3$ & 19,6 \\
\hline Нижнее Приангарье & 2083 & 635 & 128 & 3,3 & $-0,03$ & 17,9 \\
\hline Юг Западной Сибири & 2188 & 617 & 137 & 3,5 & 0,07 & 13,7 \\
\hline Среднее Поволжье & 1610 & 578 & 124 & 2,8 & $-0,1$ & 20,5 \\
\hline
\end{tabular}

*Примечание. Объем родов и видов учтен в авторской трактовке соответствующих флористических изданий ${ }^{1}[1,6,13,14]$.

Уровень богатства этих флор обусловлен различием физико-географических условий современных и прошлых эпох, особенностями флорогенеза этих терри-

1 Конспект флоры Иркутской области (сосудистые растения) / под редакцией Л. И. Малышева. Иркутск: Изд-во ИГУ, 2008. 327 с. 
торий. В пределах Восточной Европы для сравнения взята флора широколиственно-еловых лесов Среднего Поволжья на границе подтайги и широколиственных лесов, имеющих неморально-бореальный облик и испытывающих влияние лесостепных ландшафтов [13].

От южной тайги, лесостепи до зоны степей юго-восточной Сибири зональное распространение имеют мелколиственные и светлохвойно-мелколиственные травяные, горные алтае-саянские субнеморальные мелколиственно-темнохвойные и липовые леса, ксерофильные ленточные травяные сосновые боры в лесостепи и степи юго-восточной части Западной Сибири [14]. Разнообразие видового состава высокое по сравнению с другими регионами насыщенность родов, семейств видами, положительное значение показателя автономности флоры объясняются сочетанием равнинных и горно-равнинных сибирских флор, а также флор восточной части Казахского мелкосопочника, эндемизмом флоры Алтая, составляющего 7\% общего видового состава.

По видовому разнообразию выделяется также флора восточного Приангарья в пределах Иркутской области ${ }^{1}$, которая объединяет подзоны флористических комплексов сосновых, а в западной части кедрово-еловых лесов, вторичных березовых лесов, чередующихся с участками настоящих и луговых степей.

В пределах Дальневосточного региона уровень видового богатства сосудистых растений бассейна нижнего течения р. Амур трудно сопоставим с флорами соседних регионов из-за разновеликости территорий и разной степени их изученности, тем не менее данные таблицы 2 дают наглядное представление о соотношении в них основных групп таксонов.

Таблица 2

Соотношение основных таксонов во флорах бассейна p. Амур и сопредельных территорий

\begin{tabular}{|l|c|c|c|c|}
\hline \multirow{2}{*}{ Регион } & \multicolumn{2}{|c|}{ Таксоны аборигенной флоры } & \multirow{2}{*}{$\begin{array}{c}\text { Адентивные } \\
\text { виды }\end{array}$} \\
\cline { 2 - 4 } & Виды & Роды & Семейства & 63 \\
\hline Западное Приохотье & 1148 & 365 & 92 & 439 \\
\hline Нижнее Приамурье & 1801 & 602 & 152 & 292 \\
\hline Среднее Приамурье & 1720 & 573 & 140 & 571 \\
\hline Южное Приамурье & 2020 & 663 & 162 & \\
\hline
\end{tabular}

Для сравнения использованы данные о видовом разнообразии аборигенной флоры южной части бассейна р. Амур в пределах Приморского края [4], часть которого хотя и не относится к бассейну р. Амур, но вместе с тем входит в установленную Р. В. Камелиным [2] Маньчжуро-Северо-Японскую подобласть СиноЯпонской области, средней части р. Амур, охватывающей долину реки от Большого до Малого Хингана в пределах Амурской области [15], а также территории Западного Приохотья [21, 22].

Сравнивая уровень видового богатства сосудистых растений Дальневосточного региона, следует отметить, что флора нижней части бассейна Амура значительно превосходит флору Западного Приохотья, относящуюся к Охотско-

1 Конспект флоры Иркутской области (сосудистые растения) / под редакцией Л. И. Малышева. Иркутск: Изд-во ИГУ, 2008. 327 с. 
Камчатской провинции Сино-Японской области Голарктики. Видовое разнообразие флоры Западного Приохотья несколько снижено в связи со значительным ухудшением природно-климатических условий к северу, что ограничивало на протяжении последнего временного отрезка распространение представителей южных восточноазиатских флор.

Наряду с этим отмечается увеличение таксономического разнообразия в сравнении с флорой нижней части бассейна р. Амур флоры южной части бассейна этой реки, объединяющей до 2020 видов из 663 родов и 162 семейств [4]. Для этой территории свойственно наличие большого количества восточноазиатских суббореальных и суббореально-субтропических элементов, находящихся на пределе своего распространения и не достигающих Нижнего Приамурья: Scirpus oligosetus, Acer komarovii, Actinidia arguta, Oplopanax elatus и др. Специфика этой территории определяется также разнообразием видов, произрастающих близ морского побережья и связанных с разнообразными местообитаниями приморской литорали: Zostera japonica, Dimeria neglecta, Kitagawia litoralis.

Сопоставима по уровню видового разнообразия флоре Нижнего Приамурья флора Среднего Приамурья, включающая 1720 таксонов, несмотря на качественные различия видового состава. Расположенные в области распространения гемибореальных лесов, представляющих зону экотона «тайга - лесостепь», эти территории обладают своеобразием, определяемым неоднородностью природных условий в различных частях амурского бассейна и особенностями флорогенеза в условиях континентального Среднего Приамурья, в пределах которого лиственничные леса южной подтайги граничат с сосняками и дубняками и лишь на самом востоке территории - с темнохвойными и хвойно-широколиственными формациями.

Также для флоры Среднего Приамурья характерно присутствие видов даурского флороценогенетического комплекса, проникающих на эту территорию из Сибири (Allium altaicum, A. nutans, Asparagus davuricus, Gypsophila davurica, Ophelia diluta и др.), которые восточнее выпадают из состава флоры [15].

Флора Нижнего Приамурья, географически занимающего промежуточное положение, содержит значительное количество общих видов со всеми вышеуказанными флорами. Южные районы, расположенные в междуречье Амур-Уссури, представлены равнинными и низкогорными территориями, растительный покров которых богат уникальными реликтами Восточной Азии: Panax ginseng, Eleutherococcus sessiliflorus, Asarum sieboldii, Phyllitis japonica, Euryale ferox, Eriocaulon komarovii и др. Небольшие по площади локусы реликтовых видов Taxus cuspidata, Arisaema amurensis, Aralia elata, Tilia amurensis и др. отмечены севернее $51^{\circ} \mathrm{c}$. ш.

Долина р. Амур в пределах 51-52 странения термофильных восточноазиатских суббореальных и суббореальносубтропических видов. Суровые природно-климатические условия, а также близость очагов многолетней мерзлоты на севере исследуемой территории препятствуют широкому расселению их в Приамурье. Наличие значительных площадей заболоченных территорий в долинах нижнего течения рек Амур, Амгунь, а также горных систем субмеридионального простирания способствует проникновению на юг гипоарктомонтанных, арктоальпийских, арктобореальных элементов (Salix 
rhamnifolia, S. polaris, S. fuscescens, Carex brunnescens, C. rariflora), сближающих флоры Западного Приохотья и северной части Нижнего Приамурья.

В результате анализа числа видов аборигенной флоры, содержащихся в группах наивысшего ранга, получаем следующие соотношения:

Сосудистые споровые - 85 (4,7\%);

Голосеменные - $12(0,7 \%)$;

Покрытосеменные - 1704 (94,6\%);

- однодольные - 535 (29,7\%);

- двудольные - 1169 (64,9\%).

Сопоставляя эти показатели с имеющимися данными сопредельных регионов Дальнего Востока, мы отмечаем общие закономерности: главенствующую роль двудольных и однодольных в ландшафтах. Голосеменные, несмотря на слабое представительство, являются эдификаторами основных формаций лесного типа растительного покрова.

Представление об особенностях зональных изменений систематического состава флоры территории, основных направлениях флорогенеза дает анализ на уровне семейств, родов и видов. Как указывал А. П. Хохряков [19], последовательность расположения ведущих семейств флоры в первой, второй триадах позволяет установить тип и подтип флоры различных регионов.

Расположение семейств по количеству видов флоры Нижнего Приамурья в основном соответствует спектру ведущих семейств российской части бассейна $\mathrm{p}$. Амур в пределах Дальнего Востока (табл. 3) [5].

Таблица 3

Ранг семейств в таксономическом спектре флоры Нижнего Приамурья и бассейна р. Амур (в пределах российской части)

\begin{tabular}{|l|c|c|c|c|}
\hline \multirow{2}{*}{ Семейства } & \multicolumn{2}{|c|}{ Нижний Амур } & \multicolumn{2}{c|}{ Российская часть бассейна Амура } \\
\cline { 2 - 5 } & $\begin{array}{c}\text { природная } \\
\text { флора }\end{array}$ & $\begin{array}{c}\text { аборигенная } \\
\text { флора }\end{array}$ & $\begin{array}{c}\text { природная } \\
\text { флора }\end{array}$ & $\begin{array}{c}\text { аборигенная } \\
\text { флора }\end{array}$ \\
\hline Asteraceae & 1 & 1 & 1 & 1 \\
\hline Poaceae & 2 & 3 & 2 & 3 \\
\hline Cyperaceae & 3 & 2 & 3 & 2 \\
\hline Rosaceae & 4 & 5 & 5 & 5 \\
\hline Ranunculaceae & 5 & 4 & 4 & 4 \\
\hline Fabaceae & 6 & 9 & 6 & 6 \\
\hline Polygonaceae & 7 & 6 & 7 & $12-13$ \\
\hline Brassicaceae & 8 & 12 & 10 & 7 \\
\hline Caryophyllaceae & 9 & 7 & 9 & 10 \\
\hline Lamiaceae & 10 & 8 & 8 & 11 \\
\hline Scrophulariaceae & 11 & 10 & 11 & 15 \\
\hline Apiaceae & 12 & 15 & 12 & 14 \\
\hline Orchidaceae & 13 & 11 & 15 & $12-13$ \\
\hline Salicaceae & 14 & 13 & $13-14$ & 18 \\
\hline Saxifragaceae & 15 & 14 & $13-14$ & 16 \\
\hline Ericaceae & 16 & 16 & $17-18$ & $17-18$ \\
\hline Juncaceae & 17 & 17 & 16 & \\
\hline Violaceae & - & 18 & & \\
\hline
\end{tabular}


Состав семейств первой триады природной и аборигенной флоры сосудистых растений указывает на принадлежность ее к флоре Cyperaceae-типа, которая по классификации А.П. Хохрякова [19] считается арктобореальновосточноазиатской. Вторая позиция семейства Cyperaceae в аборигенной флоре региона обеспечивается значительным разнообразием родов и видов восточноазиатского происхождения.

По составу второй триады семейств рассматриваемые флоры несколько отличаются. Положение семейства Ranunculaceae на четвертой позиции определяет отнесение аборигенной флоры к Ranunculaceae-подтипу, т. е. к флорам луговым и горным. Выход на четвертую позицию семейства Rosaceae в природной флоре Нижнего Приамурья объясняется значительным участием в его составе адвентивного элемента (Potentilla argentea, P. intermedia, Geum allepicum, Chamaerhodos erecta). Ведущее положение семейств Polygonaceae, Caryophyllaceae, Lamiaceae, Fabaceae, Scrophulariaceae, Orchidaceae с незначительными изменениями рангов раскрывает особенности аборигенной флоры региона. Следует особенно подчеркнуть ведущее положение семейства Polygonaceae, занимающего шестое место в ранге семейств аборигенной флоры, что является специфичной особенностью российской части бассейна Амура, на которую ранее уже было обращено внимание [5] как на определяющую «амурский», тяготеющий к субтропическому подтипу, вариант флоры в ряду флор Голарктики. Связано это с преобладанием в составе этого семейства родов Persicaria, Truellum, Fallopia, центр видового разнообразия которых расположен в субтропических областях Восточной Азии.

В таблице 4 приведен головной спектр наиболее крупных по числу видов семейств Нижнего Приамурья. В десяти крупнейших семействах семейственновидового спектра содержится 935 видов, что составляет более половины всей флоры $(51,8 \%)$.

Таблица 4

Число видов в наиболее крупных семействах

\begin{tabular}{|c|c|c|c|c|c|c|c|}
\hline \multirow{3}{*}{ Семейство } & \multicolumn{3}{|c|}{ Количество } & \multirow{3}{*}{ Семейства } & \multicolumn{3}{|c|}{ Количество } \\
\hline & \multirow[b]{2}{*}{ роды } & \multicolumn{2}{|c|}{ виды } & & \multirow[b]{2}{*}{ роды } & \multicolumn{2}{|c|}{ виды } \\
\hline & & $\begin{array}{c}\text { абсо- } \\
\text { лютное }\end{array}$ & $\begin{array}{l}\text { в \% от } \\
\text { флоры }\end{array}$ & & & $\begin{array}{c}\text { абсо- } \\
\text { лютное }\end{array}$ & $\begin{array}{l}\text { в \% от } \\
\text { флоры }\end{array}$ \\
\hline Asteraceae & 57 & 185 & 10,3 & Polygonaceae & 12 & 59 & 3,3 \\
\hline Cyperaceae & 13 & 172 & 9,6 & Caryophyllaceae & 19 & 54 & 3,0 \\
\hline Poaceae & 48 & 154 & 8,4 & Lamiaceae & 20 & 50 & 2,8 \\
\hline Ranunculaceae & 26 & 89 & 5,0 & Fabaceae & 17 & 45 & 2,5 \\
\hline Rosaceae & 26 & 82 & 4,5 & Scrophulariaceae & 17 & 44 & 2,4 \\
\hline
\end{tabular}

Во флоре Нижнего Приамурья, как и повсеместно, в различных областях Голарктики господствует семейство Asteraceae - 185 видов, что составляет 10,4\% общего числа флоры $[7-10,16,19]$. Абсолютное и относительное разнообразие этого семейства ярко выражено в различных частях территории - в южной равнинной части за счет разнообразия видов и родов амурского лесного флористического комплекса широколиственных лесов, петрофильных скальноопушечных, скальных ценоэлементов, пойменного лугового комплекса. На мас- 
сивных поднятиях северной половины Нижнего Приамурья, находящихся в субокеаническом секторе Притихоокеанья, роль семейства несколько снижена. Оно уступает ведущую позицию семейству Сурегаceae, которое достигает наивысших показателей за счет видового и родового разнообразия представителей горнотудрового флористического комплекса.

Семейства Сурегаcеае, Роасеае, объединяющие соответственно 172 (9,6\%) и 154 таксона $(8,4$ \%), представленные набором специфичных видов на горных системах, в лесных и луговых формациях долины Амура. Видовое богатство семейства Cyperaceaе связано преимущественно с разнообразием рода Carex, представители которого освоили разнообразные экотопы бассейна р. Амур от равнин и побережья моря до подгольцового и гольцового поясов горных систем, обрамляющих долину реки. В южных равнинных участках Приамурья родовое разнообразие семейства Cурегасеае увеличивается за счет родов Rhynchospora, Fimbristylis, Cyperus, а в северных горных системах - Eriophorum, Carex и т. д. Представители семейства Poасеае, занимающего третье место по богатству и разнообразию, произрастают на открытых местообитаниях в условиях речных пойм, морского побережья, горных тундр, а также в составе лесных сообществ, в различных условиях и в ряде случаев выступают в качестве ценозообразователей. Виды рода Calamagrostis формируют пойменные вейниковые, вейниковоразнотравные, осоково-вейниковые луга на обширных пространствах равнинных территорий, родов Poa - на каменистых обнажениях, осыпях, Ptilagrostis, Trisetum - в горно-тундровых группировках, Glyceria, Phragmites, Zizania, Eragrostis - по берегам рек и озер.

Традиционно считается, что семейство Ranunculaceae определяет луговоальпийские черты флоры. В Приамурье семейство Ranunculaceae характеризуется максимальными показателями разнообразия в условиях равнинных территорий и низкогорий преимущественно на юге региона в зоне кедровошироколиственных лесов. С увеличением высоты над уровнем моря оно уступает свои позиции семейству Rosaceae.

Лесные гумидные черты флоры Нижнего Приамурья ярко выражены в видовом разнообразии семейств Lamiaceae, Scrophulariaceae, которые наряду с Asteraceae, Cyperaceae, Poaceae входят в десятку ведущих семейств, а также семейств Orchidaceae, Apiaceae, Violaceae, Campanulaceae, Convallariaceae, Liliaceae, Rubiaceae, занимающих соответственно 12-ю, 16-ю, 19-ю, 20-ю, 23-ю, 24-ю, 25-ю позиции семейственного спектра.

Во флоре среднегорий Нижнего Приамурья, как и всего Дальнего Востока, также проявляются черты гумидного климата, что отличает его от флор сопредельных территорий Восточной Сибири и подчеркивает богатство видов семейства Caryophyllaceae, входящего в десятку ведущих семейств региона, а также семейств Brassicaceae, Saxifragaceae, Ericaceae, Salicaceae, занимающих соответственно 13-ю, 15-ю, 17-ю, 19-ю позиции семейственного спектра.

Семейств, представленных во флоре одним видом - 40 (2,2\% флоры, Нижнего Приамурья), двумя-тремя видами - 36 (4,9\%), четыре-пять видов содержится в 22 семействах $(5,2 \%)$. Явление неудокомплектованности семейств видами и родами объясняется тем, что значительная их часть является реликтовой. Наиболее древние группы сосудистых растений представлены в современной флоре 
монотипными и олиготипными семействами Nelumbonaceae, Adiantaceae, Cabombaceae, Phrymaceae, Salviniaceae, Taxaceae, Trapellaceae, Penthoraceae и др. Большое значение имеют также проявления «краевых эффектов», которые связаны с закономерным снижением участия представителей различных флороценогенетических комплексов на границах своего распространения в пределах зонально-климатического экотона. Основное разнообразие семейств Schisandraceae, Chloranthaceae, Smilacaceae, Aristolochiaceae, Actinidiaceae, Dioscoreaceae приходится на субтропические и тропические области Восточной Азии, а семейств Empetraceae, Diapensiaceae, Parnassiaceae, Tofieldiaceae - на холодные и умеренно холодные, преимущественно горные области Азии и Северной Америки. В составе флоры Нижнего Приамурья они представлены одним-двумя, реже тремя видами.

Несколько иное соотношение прослеживается в семейственно-родовых спектрах. По количеству родов семейства флоры образуют следующий нисходящий ряд:

Asteraceae -56

Poaceae - 48

Ranunculaceae - 26

Rosaceae - 26

Orchidaceae - 25
Lamiaceae - 20

Apiaceae - 20

Caryophyllaceae - 19

Fabaceae - 17

Scrophulariaceae - 17 .

79 семейств содержат по одному роду, 25 - по два рода, 13 - по три рода, 11 - по четыре рода.

Всего во флоре Нижнего Приамурья выявлено 602 рода. Видовое разнообразие наиболее крупных родов флоры представлено в таблице 5. Анализ родового спектра флоры Нижнего Приамурья свидетельствует о неравномерном распределении видов среди родов флоры. Десятка ведущих родов флоры охватывают 335 видов, или $18,7 \%$ всей флоры.

Таблица 5

Число видов в наиболее крупных родах

\begin{tabular}{|l|c|c|l|c|c|}
\hline \multicolumn{1}{|c|}{ Род } & $\begin{array}{c}\text { Число } \\
\text { видов }\end{array}$ & $\begin{array}{c}\text { Доля от всей } \\
\text { флоры, \% }\end{array}$ & \multicolumn{1}{|c|}{ Род } & $\begin{array}{c}\text { Число } \\
\text { видов }\end{array}$ & $\begin{array}{c}\text { Доля от всей } \\
\text { флоры, \% }\end{array}$ \\
\hline Carex & 125 & 7,0 & Poa & 21 & 1,2 \\
\hline Artemisia & 32 & 1,8 & Saussurea & 21 & 1,2 \\
\hline Salix & 32 & 1,8 & Potentilla & 20 & 1,1 \\
\hline Viola & 23 & 1,3 & Juncus & 19 & 1,0 \\
\hline Saxifraga & 23 & 1,3 & Calamagrostis & 19 & 1,0 \\
\hline
\end{tabular}

Соотношение численности видов и родов может служить в качестве показателя флорогенетических тенденций [17]. Высокая видовая насыщенность родов трактуется как результат проявления автохтонных тенденций в развитии флоры. Для флоры Нижнего Приамурья соотношение числа видов и родов составляет 2,9:1, что может свидетельствовать о преобладании аллохтонных процессов в становлении флоры над автохтонными. Бедность видового разнообразия родов и семейств объясняется сложностью процессов становления флоры, в котором немалую роль сыграло изменение физико-географической обстановки в конце 
плиоцена - плейстоцене, вызвавшее обеднение флоры, моно- и олиготипность многих реликтовых родов и семейств. Также большое число родов и семейств, бедных видами, свидетельствует о сложности процессов флорогенеза и о влиянии миграций в освоении суровых по климатическим параметрам горных и равнинных территорий бассейна р. Амур. Лишь немногим из них удалось приспособиться к этим экстремальным условиям. Некоторые роды увеличили численное представительство за счет процессов видообразования. К ним относятся роды Carex, Saxifraga, Salix, Deschampsis, Ptilagrostis, Saussurea и другие [3, 11, 20].

Л. И. Малышевым [7] показано, что соотношение числа видов и родов определяется криволинейной зависимостью. Им был предложен более точный показатель флористической оригинальности, представляющий собой относительную разницу между реальным и ожидаемым числом видов [24]. Были рассчитаны коэффициенты оригинальности флористических районов, выделенных в пределах Нижнего Приамурья, согласно которым центрами автохтонного развития флоры являются преимущественно горные системы. Для них отмечается повышение коэффициента флористической оригинальности от 10 (горная система СихотэАлинь, хр. Баджальский) до 15,1 (хр. Ям-Алинь), что свидетельствует уже о сбалансированности автохтонных и аллохтонных тенденций в процессе флорогенеза этих территорий.

Расположение родов Нижнего Приамурья по видовому богатству сопоставимо с таковым для российской части бассейна р. Амур (табл. 6) [5]. Отличается положение родов Salix, Viola, Saxifraga, Poa, Saussurea, Calamagrostis, что определяет специфику «нижнеамурской» части бассейна р. Амур. В пределах Нижнего Приамурья отмечается перекрывание краевых зон ареалов арктоальпийских, арктобореальных, гипоарктомонтанных, бореальных, суббореальных видов родов Salix, Poa, Calamagrostis, а также уменьшение числа видов родов Viola, Saussurea, связанное с градиентом их разнообразия в результате выпадения суббореально-субтропических, лесостепных представителей этих родов в южной и западной частях бассейна Амура.

Таблица 6

Ранг родов в таксономическом спектре флоры Нижнего Приамурья и бассейна р. Амур (в пределах российской части)

\begin{tabular}{|l|c|c|l|c|c|}
\hline \multirow{2}{*}{ Род } & \multicolumn{2}{|c|}{ Ранг таксонов } & \multirow{2}{*}{ Род } & \multicolumn{2}{c|}{ Ранг таксонов } \\
\cline { 2 - 3 } \cline { 5 - 6 } & $\begin{array}{c}\text { Нижнее } \\
\text { Приамурье }\end{array}$ & $\begin{array}{c}\text { российская часть } \\
\text { бассейна р. Амур }\end{array}$ & & $\begin{array}{c}\text { Нижнее } \\
\text { Приамурье }\end{array}$ & $\begin{array}{c}\text { российская часть } \\
\text { бассейна р. Амур }\end{array}$ \\
\hline Carex & 1 & 1 & Poa & 6 & 7 \\
\hline Artemisia & 2 & 2 & Saussurea & 7 & 5 \\
\hline Salix & 3 & 4 & Potentilla & 8 & 8 \\
\hline Viola & 4 & 3 & Juncus & 9 & 10 \\
\hline Saxifraga & 5 & 6 & Calamagrostis & 10 & - \\
\hline
\end{tabular}

Отмечается резкий перевес числа видов в роде Carex над другими в родововидовом спектре, что характерно для многих бореальных флор Голарктики.

Разнообразие родов Artemisia, Potentilla, Saussurea, Salix, Calamagrostis, Viola флоры Нижнего Приамурья на различных участках объясняется увеличением доли влияния на горных системах арктоальпийских, гольцовых, гипоарктомон- 
танных, а на равнинных территориях, в пределах низкогорий - бореальных и суббореальных неморальных элементов во флорах.

Среди представителей рода Saxifraga преобладают арктоальпийские виды, широко распространенные в высоких широтах. Наибольшего разнообразия они достигают в экстремальных условиях крупных горных структур Северного Сихотэ-Алиня, хребтов Баджальский, Ям-Алинь, Дуссэ-Алинь [21].

Флористическая роль рода Salix, как уже это ранее отмечалось, закономерно повышается на горных системах, а также на равнинах, в пределах которых его представители, отличаясь невысоким разнообразием, выступают в роли важнейших ценозообразователей в поймах рек, зарастании аллювиальных отложений [8, $11,12,21]$. Несмотря на то, что по числу видов роды Ledum, Cassiope, Empetrum не входят в первую десятку флористического спектра их роль, как и родов Saxifraga, Salix, необычайно высока в горных системах и на побережье в условиях влияния морского климата.

Максимальный перепад видового разнообразия наблюдается в родах Viola, Potentilla, Juncus и связан с резким его падением к северу, от равнинных, низкогорных территорий к среднегорным.

Таким образом, анализ структуры основных таксономических единиц флоры Нижнего Приамурья свидетельствует о ее неоднородности. По уровню видового разнообразия она превосходит большинство флор зонального экотона южного предела распространения таежных экосистем Голарктики. Отмечается закономерное увеличение видового разнообразия большей части семейств и родов флоры с севера на юг. Спектр ведущих по числу видов семейств и родов соответствует географическому положению территории (ведущее положение в семейственном спектре Asteraceae, Cyperaceae, Poaceae, Ranunculaceae, Rosaceae, Polygonaceae, в родовом спектре Carex, Artemisia, Salix, Viola, Saxifraga, Poa, Saussurea). Специфика флоры определяется сочетанием элементов бореальной и суббореальной флор Восточной Азии.

Заключение. Флора Нижнего Приамурья объединяет 2240 видов сосудистых растений из 760 родов и 158 семейств. Аборигенная флора насчитывает 1801 вид из 602 родов и 152 семейств. Адвентивный комплекс представлен 439 видами из 256 родов и 56 семейств, что составляет 19,6\% природной флоры. Своеобразие флоры Нижнего Приамурья определяется сочетанием признаков лесных бореальных и суббореальных восточноазиатских флор.

Спектр ведущих семейств характеризует флору Нижнего Приамурья как арктобореально-восточноазиатскую (Суреraceae-тип) с лугово-горными чертами (Ranunculaceae-подтип). Семейство Polygonaceae определяет «амурский», тяготеющий к субтропическому подтипу вариант флоры в ряду флор Голарктики. Лесные гумидные черты выражены в видовом разнообразии семейств Lamiaceae, Scrophulariaceae, Orchidaceae, Apiaceae, Violaceae, Campanulaceae, Convallariaceae, Liliaceae, Rubiaceae. Специфика флоры «нижнеамурской» части бассейна р. Амур определяется на родовом и видовом уровнях.

\section{Литература}

1. Бакин О. В., Рогова Т. В., Ситников А. П. Сосудистые растения Татарстана. Казань: Изд-во Казан. ун-та, 2000. 496 с. Текст: непосредственный. 
2. Камелин Р. В. Важнейшие особенности сосудистых растений и флористическое районирование России // Проблемы ботаники Южной Сибири и Монголии. Барнаул: Издво АГУ, 2002. С. 36-41. Текст: непосредственный.

3. Кожевников А. Е. Сытевые (семейство Суреraceae Juss.) Дальнего Востока России (современный таксономический состав и основные закономерности его формирования). Владивосток: Дальнаука, 2001. 275 с. Текст: непосредственный.

4. Кожевников А. Е. Сосудистые растения Приморского края: флористикотаксономическая структура биоразнообразия и современное состояние его охраны // Ботанические исследования в Азиатской России: материалы ХІ съезда Русского ботанического общества (18-22 августа 2003 г., Новосибирск-Барнаул). Барнаул: АзБука, 2003. Т. 1. С. 350-352. Текст: непосредственный.

5. Кожевников А. Е., Кожевникова 3. В. Флора бассейна реки Амур (Российский Дальний Восток): таксономическое разнообразие и пространственные изменения таксономической структуры // Комаровские чтения. Владивосток: Дальнаука, 2007. Bып. LV. С. 104-183. Текст: непосредственный.

6. Крюкова М. В. Сосудистые растения Нижнего Приамурья. Владивосток: Дальнаука, 2013. 354 с. Текст: непосредственный.

7. Малышев Л. И. Зависимость флористического богатства от внешних условий и исторических факторов // Ботанический журнал. 1969. Т. 54, № 8. С. 1137-1147. Текст: непосредственный.

8. Малышев Л. И. Флористические спектры Советского Союза // История флоры и растительности Евразии. Ленинград: Наука, 1972. С. 17-40. Текст: непосредственный.

9. Малышев Л. И. Количественный анализ флоры: пространственное разнообразие, уровень видового богатства и репрезентативность участков обследования // Ботанический журнал. 1975. Т. 60, № 11. С. 1537-1550. Текст: непосредственный.

10. Малышев Л. И. Экология флористического богатства Северной Евразии // Ботанический журнал. 2003. Т. 88, № 8. С. 28-36. Текст: непосредственный.

11. Недолужко В. А. Хорология арборифлоры Российского Дальнего Востока // Комаровские чтения. Владивосток: Дальнаука, 1997. Вып. XLIII. С. 82-127. Текст: непосредственный.

12. Нечаев А. П. Аллювий и растительность в поймах горных рек Приамурья // Амурский сборник. Хабаровск: Приамур. фил. Геогр. о-ва СССР, 1960. № 2. С. 168-176. Текст: непосредственный.

13. Рогова Т. В. Закономерности фиторазнообразия зонального экотона (на примере южной границы восточно-европейских хвойно-широколиственных лесов): автореферат диссертации на соискание ученой степени доктора биологических наук. Екатеринбург, 2001. 41 с. Текст: непосредственный.

14. Силантьева М. М. Флора Алтайского края: анализ и история формирования: автореферат диссертации на соискание ученой степени доктора биологических наук. Новосибирск, 2008. 35 с. Текст: непосредственный.

15. Старченко В. М. Флора Амурской области (состав, анализ, вопросы охраны): автореферат диссертации на соискание ученой степени доктора биологических наук. Владивосток, 2008. 36 с. Текст: непосредственный.

16. Тахтаджян А.Л. Флористические области земли. Ленинград: Наука, 1978. 247 с. Текст: непосредственный.

17. Толмачев А. И. Введение в географию растений. Ленинград: Изд-во ЛГУ, 1974. 244 с. Текст: непосредственный.

18. Толмачев А. И. Методы сравнительной флористики и проблемы флорогенеза. Новосибирск: Наука, 1986. 196 с. Текст: непосредственный.

19. Хохряков А. П. Таксономические спектры и их роль в сравнительной флористике // Ботанический журнал. 2000. Т. 85, № 5. С. 1-11. Текст: непосредственный. 
20. Цвелёв Н. Н., Пробатова Н. С. Злаки России. Москва: Товарищество научных изданий КМК, 2019. 646 с. Текст: непосредственный.

21. Шлотгауэр С. Д. Растительный мир субокеанических высокогорий. Москва: Наука, 1990. 224 с. Текст: непосредственный.

22. Шлотгауэр С. Д., Крюкова М. В., Антонова Л. А. Сосудистые растения Хабаровского края и их охрана. Владивосток; Хабаровск: Изд-во ДВО РАН, 2001. 195 с. Текст: непосредственный.

22. Юрцев Б. А. Флора как природная система // Бюллетень Московского общества испытателей природы. Отделение Биологии. 1982. Т. 87, вып. 4. С. 3-22. Текст: непосредственный.

23. Юрцев Б. А., Камелин Р. В. Основные понятия и термины флористики. Пермь: Изд-во ПГУ, 1991. 80 с. Текст: непосредственный.

24. Malyshev L. I. Some quantitative approaches to problems of comparative florisrics // Quantitative approaches to phytogeography. Kluwer, Dordrecht, 1991. Р. 15-33. Текст: непосредственный.

Статья поступила в редакиию 11.10.2021; одобрена после рецензирования 08.11.2021; принята к публикациии 06.12.2021.

\title{
TAXONOMIC STRUCTURE OF THE FLORA OF THE LOWER AMUR REGION
}

\author{
Mariya V. Kryukova \\ Dr. Sci. (Biol.) \\ Institute of Water and Ecology Problems FEB RAS \\ 56 Dikopoltseva St., Khabarovsk 680000, Russia \\ flora@ivep.as.khb.ru
}

Abstract. The article presents an analysis of the taxonomic structure of the flora of vascular plants in the Lower Amur region. The flora of the Lower Amur Region includes 2240 species from 760 genera and 158 families, which is $80 \%$ of the species composition of the Russian part of the River Amur basin. The native flora unites 1801 species from 602 genera and 152 families. The adventive complex is represented by 439 species from 256 genera and 57 families, which is $19.6 \%$ of the natural flora. The species diversity, quantitative characteristics of the aboriginal and adventive flora of vascular plants in the Lower Amur region are comparable to those of the southern limit of the distribution of taiga ecosystems in the Holarctic. We have determined the place of the flora of reservoirs of the Lower Amur in the flora system of the River Amur basin. The spectrum of the leading families and genera in terms of the number of species corresponds to the geographical position of the territory (leading position in the family spectrum of Asteraceae, Cyperaceae, Poaceae, Ranunculaceae, Rosaceae, Polygonaceae, in the generic spectrum - Carex, Artemisia, Salix, Viola, Saxifraga, Poa, Saussurea). The specificity of the flora is determined by the combination of elements of the boreal and subboreal flora of East Asia.

Keywords: flora, species, genus, family, taxonomic spectrum, species diversity, the Lower Amur region.

\section{For citation}

Kryukova M. V. Taxonomic Structure of the Flora of the Lower Amur Region. Bulletin of Buryat State University. Biology, Geography. 2021; 4: 16-28 (In Russ.).

The article was submitted 11.10.2021; approved after reviewing 08.11.2021; accepted for publication 06.12.2021. 